\title{
The distribution of aquatic macrophytes on Danube River beetwen Calarasi and Braila
}

\author{
Ion VASILEAN ${ }^{1}$, Ina VASILEAN ${ }^{2}$, Daniela Cristina IBĂNESCU ${ }^{1 *}$ \\ ${ }^{1}$ Department of Aquaculture, Environmental Science and Cadastre, Faculty of Food Science and \\ Engineering, "Dunarea de Jos" University of Galati, Romania, \\ ${ }^{2}$ Department of Food Science and Engineering and Applied Biotechnology, Faculty of Food Science and \\ Engineering, "Dunarea de Jos" University of Galati, Romania; \\ * corresponding author: dgheorghe@ugal.ro
}

Bulletin USAMV series Agriculture 72(1)/2015

Print ISSN 1843-5246; Electronic ISSN 1843-5386

DOI 10.15835/buasvmcn-agr: 11131

\begin{abstract}
The presence of the aquatic vegetation, besides the creation of normal conditions for growth of juvenile fish and other aquatic organisms, also represents a source of their food, constituting together an important organic fertilizer. The aquatic vegetation is a permanent component of water shore areas but not an exclusive one. It is fixed on a base of roots or strong rhizomes which crosses, most of the times, a water column, getting in contact with the atmosphere.

The purpose of this paper is to establish the quantitative and qualitative structure of aquatic macrophytes (especially in the coast) on Danube River. The sampling was done in the Danube River, Călăraşi and Brăila areas (kmD 375 - 175), in July 2011. The plants samples were weighed to determine their biomass (wet and dry). All identified macrophytes species belonged to the same class (Monocotyledoneae), but to different families: Cyperacee, Butomaceae and Potamogetonaceae respectively. Macrophytes had a poor representation in every work point, with little exceptions: From quantitative point of view, in many work points macrophytes were missing. Total macrophyte biomass varied from $25.14 \mathrm{~g} / \mathrm{m}^{2}$ to $171.9 \mathrm{~g} / \mathrm{m}^{2}$.
\end{abstract}

Keywords: aquatic plants, emersion flora, macrophytes.

\section{INTRODUCTION}

The aquatic macrophytes are permanent components of water shore areas but not an exclusive one. It is fixed on a base of roots or strong rhizomes which crosses, most of the times, a water column, getting in contact with the atmosphere. Macro coastal vegetation is classified according to the depth of the water. Thus, there are three types of vegetation with different characteristics: harsh flora, emersion flora with aerial leaves and emersion flora with floating leaves.

\section{AIMS AND OBJECTIVES}

The aim of this paper is to establish quantitative and qualitative structure of aquatic macrophytes on the Danube River, Calarasi - Braila section.

\section{MATERIALS AND METHODS}

Generally, a study of ecosystem macrophytes implies the establishment of following aspects:

- The surface occupied by macrophytes, the degree of basin coverage respectively. It can be determined for the entire macrophyte complex, or separately for every species, being expressed in \% per total basin surface.

- The dimension and quality composition of macrophytes.

- For establishing macrophytes density, it was user a square wooden frame, immersed in river water with the help of some weights attached to its corners. All the plants that are found in that perimeter were collected and numbered in warder to establish density per square meter. 
Tab. 1. The qualitative and quantitative distribution of macrophyte species

\begin{tabular}{|c|c|c|c|c|c|c|c|}
\hline \multirow{2}{*}{\multicolumn{2}{|c|}{$\begin{array}{c}\text { Critical work } \\
\text { points } \\
\text { Wet matter, }\left(\mathrm{g} / \mathrm{m}^{2}\right)\end{array}$}} & \multicolumn{2}{|c|}{ Scirpus maritimus L. } & \multicolumn{2}{|c|}{ Butomus umbrellatus $L$. } & \multicolumn{2}{|c|}{$\begin{array}{c}\text { Potamogeton fluitans } \\
\text { Roth. }\end{array}$} \\
\hline & & $\begin{array}{l}\text { Dry matter, } \\
\left(\mathrm{g} / \mathrm{m}^{2}\right)\end{array}$ & $\begin{array}{c}\text { Wet } \\
\text { matter, } \\
\left(\mathrm{g} / \mathrm{m}^{2}\right)\end{array}$ & $\begin{array}{l}\text { Dry matter, } \\
\left(\mathrm{g} / \mathrm{m}^{2}\right)\end{array}$ & $\begin{array}{c}\text { Wet } \\
\text { matter, (g/ } \\
\left.\mathrm{m}^{2}\right)\end{array}$ & $\begin{array}{l}\text { Dry matter, } \\
\left(\mathrm{g} / \mathrm{m}^{2}\right)\end{array}$ & \\
\hline \multirow{2}{*}{$\begin{array}{c}\text { CP 01 } \\
\text { KmD } \\
(347-343)\end{array}$} & LSh & $\mathrm{NI}$ & $\mathrm{NI}$ & $\mathrm{NI}$ & $\mathrm{NI}$ & $\mathrm{NI}$ & $\mathrm{NI}$ \\
\hline & RSh & NI & NI & $\begin{array}{c}25.14- \\
38.60\end{array}$ & $\begin{array}{l}4.20- \\
17.95\end{array}$ & NI & NI \\
\hline \multirow{2}{*}{$\begin{array}{c}\text { CP 02 } \\
\text { KmD } \\
(342-341)\end{array}$} & $\mathrm{LSh}$ & $\mathrm{NI}$ & $\mathrm{NI}$ & $\mathrm{NI}$ & $\mathrm{NI}$ & $\mathrm{NI}$ & $\mathrm{NI}$ \\
\hline & RSh & NI & NI & $\begin{array}{c}11.88- \\
24.68 \\
\end{array}$ & $\begin{array}{l}1.78- \\
2.77\end{array}$ & $\begin{array}{c}25.53- \\
44.42 \\
\end{array}$ & $\begin{array}{c}5.56- \\
8.44 \\
\end{array}$ \\
\hline \multirow{2}{*}{$\begin{array}{c}\text { CP } 03 \\
\text { KmD } \\
(329-325)\end{array}$} & LSh & 141.06 & 30.94 & $\mathrm{NI}$ & $\mathrm{NI}$ & $\mathrm{NI}$ & $\mathrm{NI}$ \\
\hline & RSh & $\mathrm{NI}$ & NI & 171.90 & 15.56 & $\mathrm{NI}$ & $\mathrm{NI}$ \\
\hline \multirow{2}{*}{$\begin{array}{c}\text { CP } 04 \\
\text { KmD } \\
(324-322)\end{array}$} & LSh & $\mathrm{NI}$ & $\mathrm{NI}$ & NI & $\mathrm{NI}$ & $\mathrm{NI}$ & $\mathrm{NI}$ \\
\hline & $\mathrm{RSh}$ & $\mathrm{NI}$ & NI & 43.05 & 29.39 & NI & NI \\
\hline \multirow{2}{*}{$\begin{array}{c}\text { CP } 07 \\
\text { KmD } 291\end{array}$} & LSh & $\mathrm{NI}$ & $\mathrm{NI}$ & 81.68 & 7.60 & $\mathrm{NI}$ & $\mathrm{NI}$ \\
\hline & $\mathrm{RSh}$ & NI & $\mathrm{NI}$ & $\mathrm{NI}$ & NI & $\mathrm{NI}$ & $\mathrm{NI}$ \\
\hline
\end{tabular}

The sampling was done in the Danube Călărași and Brăila areas (kmD 375 - 175). The sector sampling was divided into eight critical work points. The macrophyte harvesting was performed from every established critical work point of every part of shore (Right shore - RS and Left shore - LS). The taxonomic identification was made after Antonescu C.S., (1951) and Florea L., (2007). The harvested plants were then weighed in order to establish biomass weight per $\mathrm{m}^{2}$. In order, to determine wet weight, the plants were previously washed and then any excess water was removed using filter paper. For dry biomass determining, was applied a standard method.

\section{RESULTS AND DISCUSSION}

The macrophytes had a poor representation in every work point, with little exceptions (there were no macrophytes found in three of the eight points). All the identified macrophytes species belonged to the same class - Monocotyledoneae, but to different families: Cyperacee, Butomaceae and Potamogetonaceae respectively. The total macrophyte biomass varied from $25.14 \mathrm{~g} / \mathrm{m}^{2}$ to $171.9 \mathrm{~g} / \mathrm{m}^{2}$. The qualitative and quantitative distribution of macrophyte species in the sampling points is given in Table 1.

\section{CONCLUSION}

A general absence of macrophytobentos can be caused by water currents of Danube river, leading to more difficult fixation conditions for macrophytes, but also due to water level variation in the river in that year period. Another cause can be attributed to clay structure of Danube shores from that area and also to the steep conformation of shores. If wooden frames were positioned near a locality, then domestically animals (horses, cows, sheep and pigs) could pass near river shore pounding the bank with their hooves and obstructing macropyte fixation, but also consuming them. Also, a better macrophyte presence was observed on right shore, being less abrupt, macrophyte fixation was easier comparing to left shore.

\section{REFERENCES}

1. Antonescu CS (1951). Plante de apă și de mlaștină, București: Editura de Stat pentru Literatură Ştiințifică şi Didactică

2. Florea L (2007). Hidrobiolgia (caiet de laborator), Editura Cermi, Iasi. 